\title{
1. Democratic firms and socialism
}

\section{TWO COOPERATIVE FIRM MODELS}

The distinction between 'internally' and 'externally' financed democratic firms was first drawn by one of the most renowned theoreticians of democratic firm control, Jaroslav Vanek (1971a, 1971b), and is generally read as contrasting self-financing firms with those funding investments with third-party capital. In point of fact, the distinction that really matters is that between (a) LMFs, i.e. cooperatives that remunerate capital separately from labour and use publicly owned means of production on the one hand, and (b) cooperatives which allocate all their revenues (labour and capital incomes) to the partners (specifically, those engaged in production in the period of time concerned from time to time) and do not remunerate capital owners as such. The latter are WMFs, which use privately owned means of production.

The self-managed firm discussed in this section is one which operates solely with borrowed funds. It is widely held that in self-managed firms, (a) all the decisions concerning production overall, the product mix and investment choices are made by the workers or their representatives, and that (b) due to the fact that the balance between the firm's aggregate revenues and operating costs is cashed by the workers, labour performs the role of an 'entrepreneurial input' (see Dubravcic 1970). A worker-controlled firm operating solely with loan capital can therefore be described as an enterprise whose workers 'hire' capital, remunerate it at a pre-fixed rate of interest and apportion the firm's earnings among themselves.

Basically, the differences between the two possible firm models can be summed up as follows: whereas in capitalistic enterprises the owners (or their representatives) carry on business solely in their own interests and, for this purpose, hire workers, pay them fixed wages or salaries and retain the residual earned (profit), in democratic (cooperative or self-managed) firms, the workers (or their representatives) carry on 
business in the interests of all the partners and, hence, borrow third-party capital, pay debt holders a fixed income (interest) and cash the residual themselves.

For this reason, democratic firms are not only non-capitalistic enterprises, but literally capsize the typical capital-labour relation prevailing in entrepreneurial firms, and it is this that justifies the claim that the establishment of a system of democratic firms gives rise to a new mode of production (see Jossa 2005, 2012b, 2012e, 2014a). A struggle for a meaningful control of workers over production - Mattick (1969, p. 152) writes - 'is clearly equivalent to the overthrow of the capitalist system'. Self-managed firms reverse the typical capital-labour for two main reasons: because (a) decisions are made by workers instead of capitalists, and because (b) capitalists switch places with workers, the former become fixed-income earners, while the latter become variable-income entrepreneurs accountable for the business resolutions they pass.

The great Italian patriot Giuseppe Mazzini wrote:

The right to the fruits of one's labour is the goal that lies ahead and it is our duty to work towards its attainment. The benefits of pooling capital and production in the same hands will be great indeed and will be reaped not only by workers, but by Society as a whole, because its effects include more solidarity, as well as higher outputs and consumption levels. Ever more numerous voluntary associations are bound to arise and their inalienable capital will be used to provide opportunities for collective work to a growing amount of workers. (Mazzini 1935, p. 489)

\section{DEMOCRATIC FIRM CONTROL STRIPS CAPITALISTS OF THEIR POWER}

Although the strong points of a system of worker-controlled firms are indeed many (see, e.g. Jossa 2014a, chs 7-10), only the crucial ones will be touched upon in this book.

By far the greatest advantage of democratic firm management is the substitution of the 'one head, one vote' principle for the 'one share, one vote' criterion. As workers would both derive great satisfaction from the exercise of decision-making powers (i.e. sovereignty) and wrest themselves free from the need to obey third-party commands, it is they that would come off best from the introduction of the 'one head, one vote' principle. On closer analysis, however, since the disempowerment of capitalists would provide a major impetus for political democracy, there would be comparable benefits for society as a whole. One of the 
authors thanks to whom the term 'capitalism' came into general use, W. Sombart, was the first to describe worker control of firms as a mode of production and a social order founded on the antithesis between those in command and those supposed to obey (see Sombart 1902/1916, ch. 19). Ever since that time, critics of capitalism have been pressing the view that the despotism with which capitalists impose their laws not only on workers, but also on politics and culture, is part and parcel of the essence of the capitalistic organisation mode of society.

In other words, this explains why the aspect of a worker-controlled firm system on which we intend to provide preferential focus is its potential for preventing capitalists from imposing their will and interests on society. As argued by Marx and Engels (1845, pp. 35-6):

The ideas of the ruling class are in every epoch the ruling ideas, i.e. the class which is the ruling material force of society is, at the same time, its ruling intellectual force. The class which has the means of material production at its disposal, has control at the same time over the means of mental production, so that thereby, generally speaking, the ideas of those who lack the means of mental production are subject to it.

A major advantage of a democratic firm system is hence its ability to help workers gain freedom and the status of fully fledged members of society - i.e. its ability to satisfy those aspirations that according to Marx were antithetical to the capitalistic mode of production and would only be met at the stage where 'the next leap forward in the material conditions of social labour and, hence, in the materiality of the productive attributes of the labourers, becomes incompatible with the capitalist social form of the production process of human life' (Kiciloff and Starosta 2007, pp. 26-7).

This advantage will be palpably clear if we focus on an economic system imagined to have become mainly (if not solely) formed of democratic firms. Compared to the circumstances prevailing today, as a result of the (near) disempowerment of capital owners, such a system can be assumed to have developed political democracy to the highest possible degree. Whoever has given some thought to the insoluble conflict between true democracy and the power of wealth will clearly appraise the crucial role that democratic firm control may play. The media, including the press and television, would cease being subservient to the interests of their owners and would no longer be monopolised by anybody (if nothing else, not by a single individual). This is the idea behind M. Adler's distinction between 'political democracy' and 'social democracy'. Although the former is described as democratic, he argues, in actual fact, that it 
resembles a dictatorship of sorts since the 'general will' it is said to express reflects the specific interests of the class in power and the underlying rationale is the liberalist principle of the atomisation of society into abstract individuals. As for the latter, it is true democracy but can only become a reality in a classless society (see Marramao 1980, p. 292). More recently, an advocate of industrial democracy such as Noam Chomsky wrote: 'of all the crises that afflict us, the growing democratic deficit may be the most severe' (2009, p. 41).

In an analysis of capitalism, Huberman raised a set of questions: 'Do we really tolerate all political and economic dissenting opinions? In ordinary times, it is true that we do not clap liberals or radicals in jail. But what happens in times of great tension, for example? And, isn't it also true', he continues, 'that jobs, power and prestige almost always go to those who do not dissent, those who are "sound" and "safe"?' (Huberman and Sweezy 1968, p. 74). Simone Weil's view is even more radical: 'all the laws guaranteeing freedom and equality in the Republic are illusions because the state is not controlled, nor could it be. It is impossible to bring about a reform of the state unless one first of all changes the system of production' (1999, p. 171).

Capitalism is typified by economic inequalities, which in turn breed political inequality. While it is true that most political systems vest voting rights in all the citizens, there can be little doubt that high-income individuals wield more political power both through their control of media, and because they can bribe politicians into acting in their favour. To some extent, the interest groups discussed in treatises on democracy might work towards redressing these imbalances and the impoverished classes of society might doubtless join forces and attempt to dismantle the power positions of industrials and bankers. In point of fact, though, since the financial resources available to the poorer classes of society, albeit organised, are bound to come short of those owned by the rich, the poor will barely succeed in combating political inequality effectively.

One effect of the unequal distribution of political power is that hardly any issues of concern for the more disadvantaged part of the population will enter the political agenda. The task of politics - problem solving - is hardly approached since the agenda is dictated by the class in power. Examples in point include the creation of public crèche facilities that less affluent families rate as one of their top priorities or the issue of democratic firm management, which is more closely linked to our working hypothesis in this book. Why has this problem never been put to the vote or, if nothing else, made the object of earnest discussion? 
To claim that democratic firm governance would bridge the cleavage between civil society and political society is but to cast the same argument in different words. Our line of reasoning goes to support the claim that markets cannot be blamed for shortcomings which are actually inherent in the mechanisms governing capitalism (see Bidet 2004, p. 82). Capital, not the market, is the enemy that the left is expected to overthrow.

\section{FURTHER REFLECTIONS ON THE RELATIONS BETWEEN POLITICAL POWER AND ECONOMIC DEMOCRACY}

In an exhaustive analysis of the benefits of democracy in general, Dahl (1989, pp. 311-13) listed a number of major strengths of economic democracy:

1. A tendency to expand its range and promote ever greater levels of freedom;

2. The development of a great many human skills that freedom of choice tends to further;

3. The availability of mechanisms capable of effectively protecting the property and interests of the citizens.

With reference to the distinction between representative and direct democracy, Norberto Bobbio wrote:

in contemporary society the domain of democracy widens both under the dual impulse of representative and direct democracy and, and even more so, as a result of increasing levels of democratisation, that is to say thanks to processes enabling individuals to play an active part in the decision-making processes of a rich array of non-political collective bodies. (Bobbio 1985, p. 147)

But there is more to this. The extension of democracy we are speaking of does not principally consist of making collective decisions, since the task of running the firm should be left with the managers. The partners will be called upon to state their opinions on major issues which do not impinge on efficiency; above all, they will have an opportunity to meet whenever they deem it appropriate in order to discuss inconveniencies associated with their work and make recommendations to the managers. And decisions supported by exchanges of opinion are fruitful in several respects. First and foremost, preferences which would have remained concealed are brought to the fore and can be properly weighed; secondly, as reflec- 
tion is stimulated by debate and each participant may build on the insight flowing from the opinions of his fellow partners, consultations can lead to solutions that would not have occurred to the participants individually. Let us add that group discussion offers scope for stating wishes and raising issues which the speakers have as yet not fully pondered and on which they will probably wish to hear the opinions of others. Thirdly, resolutions passed following in-depth discussion gain added legitimacy and a moral authority which individual decisions necessarily lack, and will consequently be implemented with greater sense of purpose (see Fearon 1998).

Inasmuch as it is true that capitalism is often praised for guaranteeing freedom and democracy, but never in its own right (see Levine 1984/1988, p. 2), a system of democratic firms will outperform capitalism in terms of breeding even higher levels of democracy. Discussing similarities between the tenets of pre-Marxian socialism and those of capitalistic democracy, MacPherson (1984) argued that both were non-scientific and non-democratic in that they did acknowledge the right of the individual to a variety of political rights, but not to fully fledged democracy. In his celebrated Development of Socialism from Utopia to Science, Engels remarked that utopian theories were those which, though designed to pursue lofty aims, were unrealistic and ineffectual. Engels's description reflects the typical mindset of advocates of capitalistic democracy who deny the very possibility of a turn to the better (see Macpherson 1984, p. 141).

As argued by Branco (2012, p. 23), in mainstream economics there is only one best solution for each economic problem and thus the purpose of policy is finding out that solution rather than weighing collective preferences or, in other words, engaging in political debate. In the realm of politics transformed into economics, he concludes, there is no place for pluralism. 'The conflict between economics and democracy does not result, therefore, from any moral weakness of economic actors but from an intrinsic incompatibility between the logic of economics and that of democracy', he concludes. In fact, this view, though widely shared, is barely convincing since the antithetical terms are not democracy and markets, but democracy and capitalism. Thanks to the application of the 'one head, one vote' principle, a democratic firm system would be fully democratic notwithstanding the retention of markets.

Lindblom has argued that while alternative forms of democracy would be badly needed for the very survival of polyarchy, no such bold grand options have been devised so far or are likely to come up in future (see 
Lindblom 1977). On this point, we dissent from him, since it is our belief that the shortcomings of formal democracy would be swept away upon the establishment of a system of democratic firms.

Our firm advocacy of economic democracy does not spring from an optimistic view of human nature or the persuasion that human beings tend to make rational decisions. As is well known, the theory that man is by nature good was propounded by Jean-Jacques Rousseau and was taken up by quite a lot of leftist thinkers. Yet, even advocates of this view will barely assume that collective decisions are, for the most part, made based on rational considerations. For our part, paraphrasing Friedrich Schiller, we wish to argue that people endowed with reason are exceptions and that most collective decisions are emotionally determined. This means that the desire to establish economic democracy is not only associated with the need to wrest power from capitalists, but also, and primarily, with the aim to educate individuals for social responsibility - a goal which is definitely beyond the reach of a society split into classes.

In the words of Stiglitz, 'unfettered markets do not work well. . . For markets to work the way markets are supposed to work, there has to be appropriate government regulation. But for that to occur, we have to have a democracy that reflects the general interests - not the interests of just those at the top' (2012, p. xxiii).

\section{REDUCED BANKRUPTCY RISKS IN DEMOCRATIC FIRMS}

Remoter insolvency risks are an additional major strength of a system of cooperative firms. As is well known, a company faces insolvency when its costs exceed revenues. Hence, the absence of the largest cost item wages and salaries - from a democratic firm system would greatly help confine insolvency risks.

In other words, the downward trend in insolvencies is the result of a major difference between capitalistic and employee-managed firms: in the former, workers take precedence over capital providers since they are paid wages or salaries irrespective of profit distributions; in the latter, the partners participate in the 'residual', which means that their incomes, though possibly paid out in monthly instalments, are calculated only after the whole of the firm's costs, including capital charges, have been settled.

An additional argument acquires relevance in this connection: if the pay rates of a democratic firm fall below the average level for the system, the partners will be tempted to leave the firm, but due to the aversion to 
the entry of newcomers postulated in the theoretical model of producer cooperatives they are likely to have difficulty getting better-paying jobs elsewhere. This means that workers earning pay rates below the system's average will face the serious inconvenience of having to put up with lesser incomes and that even the resulting lesser inter-firm workforce mobility rates will go to reduce risks of insolvency. Remote bankruptcy risks are mutually inter-related with an additional typical characteristic of cooperative firms such as lower risks of dismissal.

As is well known, a cooperative may respond to declining demand by reducing working hours instead of laying off part of the workforce. On the other hand, since layoffs are the exception because of lesser insolvency risks, employee-managed firms offer the additional advantage of making jobs both safer and more lasting.

As for competition, which in capitalist systems is often very tough, it is greatly cooled off as a result of reduced insolvency risks. A firm which is aware that it will not go bankrupt is free to resolve not to engage in competition at all. For instance, provided the partners are prepared to accept lower incomes, the firm may decide to grant them more free time by reducing daily working hours or the working week. In such a situation, i.e. when no bankruptcy risks are looming, competition, even though sharp, will barely be an evil since individual firms will have the option of engaging in the competitive race or reducing incomes.

In the main, the effect of lesser insolvency risks is to damp down the impact of oppressive market mechanisms as the main obstacles to the free choices of workers. As said above, the workers may decide to cut their individual work inputs and adopt a variety of different organisation modes without facing risks of default, and this, in turn, will reduce the sway of markets - i.e. inanimate things such as production means - over man.

Accordingly, the materialist approach to life, the prioritisation of the economic factor in individual and social choices, would become less pervasive in a system of democratic firms than it is in our present world order. And given that maximum efficiency - let this be repeated - is mainly necessitated by competition, our train of reasoning prompts the conclusion - that Marx seems to have denied - that socialism may even be implemented in a single country (see Tomba 2013, p. 362). Let us add that this is an additional reason why a system of democratic firms would help suppress the sway of capital over labour. 


\section{THE OWNERSHIP ISSUE}

At this point, it is time to identify the actual owner of the assets of worker-controlled firms. Indeed, although recent studies have appropriately recommended a shift of attention from the ownership issue proper to the far more relevant point of firm control, there can be little doubt that especially from the vantage of a Marxist the ownership issue is no less important.

To start with, let us specify that the debts of an LMF must be liabilities of its partners. Otherwise, these might leave the firm upon the first signs of a downturn and shirk their financial obligations. As far as the capital assets and stock inventories of a cooperative are concerned, it is generally held that they cannot be rated as the property of the partners for two main reasons: firstly, because the partners cannot freely dispose of their interests in the firm; secondly, because exiting partners, though offered the option of retaining their loans as creditors or having them refunded, are not entitled to any portion of the assets of their firm. Ever since the times of the ancient Romans, an ownership right has been construed as a ius utendi et abutendi. As a result, a person not entitled to dispose of an asset is not its rightful owner.

In sum, as a cooperative's capital assets can neither be owned by capitalists (who are only providers of funds) nor by the workers, they must necessarily be the property of the state - as argued by Vanek in a celebrated full-scale textbook on this subject in 1970. Be that as it may, given that the right to run the cooperative remains firmly vested in the workers, the state's ownership title virtually comes to nothing.

While this goes to support the view that the resulting nationalisation of production means is one of the reasons justifying the equation of a worker-controlled firm system with socialism (see further on), id it is worth re-emphasising that the crucial point is the right of the workers to run firms on their own, rather than the public ownership of means of production. 1

An additional point to be clarified is what becomes of a cooperative firm upon a downturn in business or bankruptcy proceedings against it. Upon perceiving the early signs of a business crisis, one or more partners might quit in the awareness that their contractual obligations would be shifted onto those resolving to stay and keep the firm going - nor could it be otherwise. This means that following the exit of one or more partners those who stay on would face the option of taking over the debts of the 
outgoing partners and keeping the firm going on their own or, conversely, closing down the firm. As mentioned before, in the latter case the debts of the firm would have to be jointly settled by all the partners, including those intending to leave.

\section{A SYSTEM OF SELF-MANAGED FIRMS AND SOCIALISM}

In the opinion of Marx and Engels, a communistic order was aimed to do away with 'the dominance of circumstances and of chance over individuals' and replace it with 'the domination of individuals over chance and circumstances' (Marx and Engels 1845-46, p. 430), and such a change in the direction of society would become feasible thanks to the reversed capital-labour relation. In Marx's view, the capital-labour contradiction in capitalism was to be traced, not to the diverging interests of these classes, but to the fact that man, far from exercising control over things, is actually under the control of inanimate things (specifically of capital as the bulk of production means). As a result, by suppressing the sway of capital and enabling workers to master and run production activities, the reversed capital-labour relation simultaneously breaks the dominion of things over man. According to Dunayevskaya (1951), Marx was right when he argued that 'only when cooperative labor replaced private labour from the ground up will social control become the natural attribute of individuals cooperating in labor and who have become thereby truly social individuals'.

In Marxian theory, the capital-labour opposition is by far the most glaring contradiction in capitalism. As a result, inasmuch as it is true that a producer cooperative system marks an end to the capital-labour contradiction, from the perspective of a Marxist it follows that the rise of such a system, far from being a necessary and inevitable development, requires the concerted efforts of forces determined to work towards its establishment. Bensaïd (2002, p. 14) sees the novelty of Marx's approach to history in its ability to decipher 'tendencies that do not have the force of law', but are already powerfully under way, while Finelli (2007, p. 128) emphasises Marx's conception of capitalism as a reversed world where 'alienation from labour and the impoverishment of the proletariat cannot exceed a certain level, at which the contradiction between the earning potential of the members of this class and the misery of their current circumstances will become so unbearable as to spark off the reversal of this reversal'. 
Tronti, for his part, has argued that the more capitalist production takes root and invades, by extension, the bulk of social relations, the more society appears as a totality shaped by production. 'In point of fact, this is just the appearance, because at the acme of capitalism . . . society as a whole becomes an appendix of production, society as a whole is reduced to the factory and, consequently, it is up to science to point up the basic relation' (Tronti 1966, pp. 49-52). To the extent this is true, the reversed capital-labour relation rids society of the sway of capital over labour and downgrades production from a dominant to a marginal component of social relations. 1

This begs the question: is it true that the 'one head, one vote' principle and the reversed capital-labour relation strip capitalists of their power and help workers gain freedom, as has been argued above? This claim is forcefully denied by Holloway. To break from capital, he writes, it is not enough to flee. Capitalism, he continues, is an active process which separates us from the means of doing, and this separation is inevitable as long as capital exists. And as long as capital exists, he contends, the system obeys the laws of capital. In Holloway's opinion, the problem is not that production means are owned by capitalists: to argue that production means are the property of capitalists is just a euphemism for the fact that capital infringes on our daily actions and deprives us of what we have produced. This, he concludes, is why the aim of the battle we have to fight is not to seize means of production, but to dismantle ownership rights and means of production at one token (Holloway 2005, pp. 208-10).

Basso (2008, p. 132), for his part, writes:

To break away from the current situation, it is not enough to reverse the circumstances prevailing today and leave the underlying logic unaltered. Inasmuch as it is true that the subjection of the individual to an abstract social power is caused by the existence of a dominant structure embodied by one specific class, the reversal of the respective positions of the factors of this relationship to the detriment of the class (previously) in power will not be enough to put an end to this subjection.

The extent to which Basso's contention is beside the point should clearly emerge from our line of reasoning in this book, which leads to the conclusion that it is not just an extreme view, but a fallacious argument.

Coming back to the subject of the reversal of the capital-labour relation, its prerequisites include:

1. A ban on the employment of hired labour in democratic firms; 
2. Remunerating borrowed capital at fixed rates of interest regardless of the bottom-line results of the firms concerned.

In light of the ideal principles of cooperation, the condition under (1) is all-important since only the abolition of hired labour may spark off a true revolution reversing the current capital-labour relation, suppressing the sway of 'things' over man and restoring the mastery of man over means of production. 月 $^{2}$

Practically speaking, however, the suppression of wage labour would not seem to be an unrenounceable aspect of the 'ideal' social organisation model expected to take the place of capitalism. On closer analysis, just as entrepreneurial firms that borrow third-party capital are a business form characterised by the fact that capitalists hire labour, take over third-party capital, reserve decision-making powers entirely for themselves and retain the whole of the 'residual', so worker-controlled firms might be described as business forms in which a number of workers borrow capital and third-party labour while reserving all decision-making powers and the 'residual' for themselves. ${ }^{1 /}$

The main conclusion suggested by the foregoing is that the ability of a system of producer cooperatives to solve the capital-labour contradiction leads to the establishment of a genuine socialist system. I $^{15}$

While there seems to be sufficient evidence that a system of producer cooperatives does give rise to a new production mode replacing capitalism in full keeping with Marx's theoretical approach, it still remains a matter for debate whether the current stage of producer cooperative theory can be rated as Marxist despite its use of methodological individualism, an approach which is usually held to be at odds with Marxism (see, inter alia, Callinicos 2005, p. 370). In a well-known book by Elster (1985), this query is convincingly answered in the affirmative.

\section{WHY IS THE BOURGEOISIE IN CONTRADICTION WITH ITSELF?}

In theory, since the 'one share, one vote' criterion is irredeemably at odds with the principles of democracy to which the bourgeois class is used to paying lip service, it is this class that might be expected to work towards disempowering capitalists.

In practical terms, though, the existence of a scientifically acceptable solution to the issue of democracy is of no consequence, since 'to accept that solution, even in theory, would be tantamount to observing society 
from a class standpoint other than that of the bourgeoisie' and 'no class can do that - unless it is willing to abdicate its power freely' (Lukàcs 1923, p. 70). The class consciousness of the bourgeoisie, Lukàcs wrote, 'is cursed by its very nature with the tragic fate of developing an insoluble contradiction at the zenith of its powers and with annihilating itself as a result of this contradiction'. Historically, he argued, this tragedy is reflected in the fact that 'even before it had defeated its predecessor, feudalism, its new enemy, the proletariat, had appeared on the scene'; politically, this tragedy became evident when the 'freedom' in whose name the bourgeoisie had fought its battle against feudalism 'was transformed into a new repressiveness' which in Lukàcs's mind is capitalistic exploitation, but which we equate with the denial of voting rights to workers in firms $(1923$, p. 80).

To understand why the bourgeoisie is blind to the fact that denying workers the right to vote in firms runs counter to its own principles, we have to bear in mind that 'when capitalism was in the ascendant ... even the ideological exponents of the rising bourgeoisie acknowledged the class struggle as a basic fact of history'; but 'In proportion as the theory and practice of the proletariat made society conscious of this unconscious, revolutionary principle inherent in capitalism, the bourgeoisie was thrown back increasingly on to a conscious defensive' (Lukàcs 1923, p. 85).

The inability of the bourgeoisie to develop a correct appreciation of the paramount role of power in economic relationships may explain why Coase (in a well-known 1937 paper) and, even more so, Alchian and Demsetz (1972) or Cheung $(1987,1992)$ could go so far as to press on us the absolutely unwarranted idea that employers wield no power in firms (see Braverman 1974; Marglin 1974; Gordon 1976; Edwards 1979; Jossa 2009).

Habermas, Offe and O'Connor argue that the crisis of liberalist democracy in the present globalised world stems from the opposition of business enterprises to state intervention in the economy and the resulting inability of the state to satisfy the demand for more welfare services coming from the citizens. Inasmuch as this is true, there is ground for arguing that thanks to the potential of a democratic firm system to defuse inter-class frictions, this opposition would, if nothing else, be considerably scaled down and the state would be free to protect the interests of workers. Quite obviously, this is an additional reason for stripping capital of all its power. ${ }^{17}$ 


\section{LUIGI EINAUDI'S APPROACH TO FIRM CONTROL}

The great Italian economist, Luigi Einaudi, devoted several articles to the 'critical scrutiny' of an idea which in his day was still 'vague and confused'. Most importantly, he cautioned against looking upon factory councils as a tool to fight a battle against capital. He argued that

If we assume that the factors of production are capital and labour it will at once strike us as evident that in our day true firm control, that is to say the power to run firms, has been wrested both from the former and from the latter and has been vested in a third factor: the entrepreneur.

In his opinion, the reason was that

capital today is a mute and submissive servant given to those who have been able to win its trust. (Einaudi 1920a, p. 849)

Einaudi's train of reasoning is clearly objectionable. While modern producer cooperative theorists endorse Einaudi's idea that the issue at stake is not suppressing capital (an absurd undertaking), but having it transferred to workers and mandating democratically elected managers to assign it to possibly effective uses, any discerning economist will smile at the idea of capital as a 'silent servant' not desirous of exercising authority. Newspaper and TV tycoons often pride themselves on not interfering with news reporting. But who will believe them? And, supposing they were telling the truth, who can deny that - wittingly or not - a journalist covering an event will often abstain from telling the whole truth if he feels that the owner of his media corporation would like the relevant piece of news not to be circulated? And this is not all, as everybody knows.

Further on in his critical analysis, Einaudi maintained that workers demanding factory councils were actually aiming to control entrepreneurs, in terms of replacing 'an absolute monarchy with a representative democracy'. Describing their attempt as 'a grandiose experiment' (and, by the same token, one 'fraught with risks'), he argued that 'no economist is in a position to predict its failure with absolute certainty' because 'we are not in the domain of logically necessary principles, but in that of experimental truth' (Einaudi 1920a, p. 850). Again, a modern economist will barely be prepared to accept Einaudi's approach, since the aim of modern cooperation theory is not so much substituting representative 
democracy for absolute monarchy, as creating the assumption for workers to switch places with capitalistic entrepreneurs and acquire the right to exercise control over their actions. Moreover, as it is clear that any such control would only be exercised ex post, on the operating result, and that the managers would in either case retain freedom to run the firm to the best of their abilities, we are prepared to subscribe to Einaudi's conclusion that even where the substitution of one type of control for the other should prove abortive in economic terms (i.e. where it should scale down production), it would nonetheless be useful in social terms if it should manage to damp down social frictions and create a less confrontational climate (Einaudi 1920b, p. 850).

In conclusion, let us emphasise that the equation of the rise of a worker-controlled firm system with the transition from absolute monarchy to representative democracy will only make sense if we think that a capitalistic entrepreneur appointing his managers is comparable to an absolute monarch and contrast him with the behaviour of the partners of a cooperative apportioning those same powers among themselves.

\section{CONCLUSION}

In summary, it is possible to argue that whenever democratic firm management is organised in such a way as to segregate labour incomes from capital incomes, it produces the effect of reversing the capital-labour relation and giving rise to a genuine socialist system depriving capitalists of (the greater part of) their power. Through the disempowerment of capital, economic democracy enhances political democracy while revealing the contradictoriness of the policies of the bourgeoisie, i.e. the fact that the opposition of this class to economic democracy is actually at odds with its very principles. Even more so, since economic democracy puts an end to the sway of things over man and makes man master of his own destiny, it is possible to argue that the materialist conception of history is much less applicable to a system of employee-managed firms than it is to a capitalistic system. 'Economic and political democracy should go hand in hand, or there is no democracy at all,' wrote Simone Weil (1999, p 177).

\section{NOTES}

1. As ownership relations are exogenously determined, the choice of the WMF or LMF model is politically determined. As pointed out by Pejovich (1982, 
p. 240), the findings of modern theoretical approaches to ownership rights are in line with Marx's claim that ownership rights have a major bearing on the way economic life is organised.

2. In point of fact, in large-size industrial firms, decisions are usually made by managers (rather than the capital-owners themselves) and in trading companies decision-making powers are vested in individuals operating with borrowed funds (that is to say, not capitalists proper). This is why some theorists (mainly those critical of the labour theory of value) have stressed the need to rethink the traditional notion of class. An interesting debate on this specific point has involved Wolff and Resnick (1982, 1983), Lindsey (1983), Houston (1983) and, especially, Poulantzas (1974), who has strongly criticised and enriched the traditional theory of social classes.

3. Tronti has argued that the only way to 'subvert bourgeois society from within capitalistic production' is 'to reverse social production relations right within the social relations in factories' (Tronti 1962, pp. 24, 30).

4. In contrast with Rawls's claim that the principle of equal freedom is only applicable to civil and political affairs (Rawls 1958), we hold it to be as relevant in economic and social phenomena. Indeed, there are reasons for arguing that just as the equal rights principle includes title to the exercise of political powers, so it should include a say in corporate decision-making processes, especially when it comes to appointing managers (see Gould 1985, p. 204).

5. Hence, we endorse the view that 'Rawls fails to point up that equal social and economic conditions are a prerequisite for political freedom' (Gould 1985, p. 204).

6. In particular, this idea is supported by Cohen and Rogers (1983) and by Bowles and Gintis (1986).

7. The major impetus that economic democracy provides for political democracy is analysed by Wolff (2012, ch. 9).

8. It is worth mentioning that the assumed lower bankruptcy frequency is only observed in the theoretical cooperative model characterised by workers earning variable incomes, whereas most real-world cooperatives are known to pay their partners fixed wages and salaries.

9. Discussing underinvestment and other issues, some authors have suggested that the partners of a worker-controlled firm should be free to sell their jobs to other workers (see Sertel 1982; Mygind 1985). In point of fact, this hypothesis sounds fairly unrealistic and we have no notice of any such case in real-world cooperatives. "What the term "labour-managed" really means is that the models being used presume there are legal prohibitions against the existence of tradable residual claims on the entire sequence of future cash flows' (Jensen and Meckling 1979, p. 475, original emphasis).

10. In the opinion of Dobb (1969, pp. 141-2), to claim that the distinctive feature of a socialist economy is not the social ownership of production means would amount to a break with the socialist tradition of the past century (see also Landauer 1959, vol. I, p. 5; Wiles 1962, ch. 1; Sweezy 1963, p. 330; Dobb 1970, pp. 50-51; and Kornai 1971, pp. 337-8). 
11. Although this is not the place to look further into this issue, it is worth mentioning at least in passing that both Berle and Means (1932) and other modern theorists of the ownership/control separation in capitalism contend that market socialism stopped being perceived as a viable alternative to capitalism when capitalists were stripped of their firm control over business enterprises.

12. 'The configuration of socialism undergoes constant change and the only thing we are able to predict, with respect to this process, is that it extends over a transitional historical time-span during which producers have consistently worked towards securing title to full self-governance' (Giuseppe Vacca 1985, p. 38). In the words of Simone Weil, 'our social system depends on coercion. Workers submit to it, but they cannot accept it. Coercion does not go with democracy' (1999, p. 170).

13. The idea of contracts of employment as a distinctive feature of capitalism is discussed in Offe (1985) and in even further depth in Screpanti (2001). In 2007, the latter author went so far as to contend that 'inasmuch as it is true that hired labour is a basic institution of capitalism, the only way to establish communism is to suppress hired labour'. Weitzman, for his part, has argued (1984, p. 147) that, as wage labour is neither necessitated by universal norms or decrees of diving powers or natural laws, nor inherent in human nature, but was created by humans under the pressure of historical forces, it is humans themselves only that can replace the wage system with a more suitable system by their free will.

14. Even the stoutest advocates of democratic firm government are prepared to admit that a certain number of wage earners are compatible with the nature of the employee-managed firm (see, inter alia, Schweickart 1992, p. 40).

15. As argued by several authors, it strikes us as surprising that Marshall, though sharing Owen's view that cooperation and socialism arose simultaneously, did not discuss the fact that they drifted apart with the passing of time.

As early as 1891, Engels wrote: 'Thanks to the economic and political development of France since 1798, for fifty years the position of Paris has been such that no revolutions could break out there without assuming a proletarian character' (Engels 1891b, pp. 13-14). The effect of this, he concluded, it that each revolution won by the workers was followed by 'a new struggle, ending with the defeat of the workers'.

17. The idea that 'economic freedom is the prerequisite for the attainment of political freedom' (Hayek 1982, p. 7) is a mainstay of liberalist thought. Strangely enough, Hayek and other liberalists reject the view that the 'one share, one vote' principle is not an essential constituent of liberalism.

18. Macchioro (2001, p. 528) has appropriately remarked that Einaudi's view of the capitalist as 'inexistent' exerted a major influence on socialist thought. 